\title{
Recent Trends in Explaining Abuse within Intimate Relationships
}

\author{
Philip Stevens* \\ ${ }^{*}$ LLB, LLM, LLD, Senior Lecturer in Criminal Law, Department of Public Law, University of Pretoria, South Africa, \\ Associate member of the Pretoria Bar; e-mail: philip.stevens@ up.ac.za.
}

\begin{abstract}
This article reflects upon abuse within intimate relationships with specific emphasis on research pertaining to the phenomena of coercive control, Stockholm syndrome and the compliant victim of the sexual sadist, advanced in order to explain the non-physical aspects of abuse within intimate relationships. The battered woman syndrome is accordingly revisited with specific emphasis on the nonvisible aspects of abuse within intimate relationships which are often underestimated and overlooked. The latter is illustrated against the backdrop of the controversial South African case of $S$ v Visser which was the first South African criminal case where these theories were addressed.
\end{abstract}

Keywords: Stockholm syndrome; Coercive control; Intimate abuse; Battered woman syndrome; Sexual sadist

Abuse within intimate relationships has been a phenomenon since time immemorial. Domestic abuse is most frequently typified in terms of the physical manifestations of abuse. As such the general approach followed in terms of the assessment of abuse is that of an incident-specific approach in which the severity of abuse is measured against the level of force or amount of injuries inflicted. More often than not, the psychological and, concomitantly, the emotional impact and manifestations of abuse are overlooked.

The reality, however, is that a domestic assault is often part of a much larger system of controlling, coercing, intimidating and violent behaviours employed by an abusive partner to control the victim. Such abuse within the intimate sphere comprises a much wider purport than merely the physical manifestation thereof, if this exists.

This article provides a prelude to the fairly novel phenomena of coercive control, the Stockholm syndrome and the compliant victim of the sexual sadist as alternative approaches towards assessing abuse within intimate relationships and the subsequent impact on the victim who either retreats towards the abuser or commits other criminal offences as a result of the abusive relationship. The latter phenomena will be addressed against the backdrop of the trial of Cézanne Visser in South Africa in 2009. ${ }^{1}$

I S V Visser Case Number CC 545/07, unreported, October 2009, also referred to as the Barbie trial. In 2009 the highly controversial Visser case resumed de novo before Eksteen AJ in the North Gauteng High Court in Pretoria. Cézanne Visser, known to South 


\section{Barbie-a synopsis}

Cézanne Visser (Visser) met Dirk Prinsloo (Prinsloo) when she was 23 years old. Prior to meeting Prinsloo, Visser failed her Bar examination and had suffered a failed relationship. Soon after she met Prinsloo, she moved in with hin. A romantic relationship arose between Visser and Prinsloo. Initially Prinsloo showered Visser with gifts and compliments and referred to her as his 'princess'. Soon after Visser moved in with Prinsloo, she was exposed to having oral sex with him. At that stage she was still naïve as to aspects involving sex, but thought that what Prinsloo expected of her was normal. At the time she met Prinsloo, Visser testified that she had an extremely low self-esteem and was very vulnerable. Prinsloo soon displayed signs of sex addiction. Visser testified that Prinsloo watched pornographic films every morning at breakfast. He requested Visser to have tattoos engraved on her body and also to have breast enlargements. Prinsloo did not get on well with Visser's parents and eventually, on his demand, the couple got a protection order under the Domestic Violence Act 116 of 1998 against Visser's parents which prohibited any means of contact between the parents and their daughter. Prinsloo also controlled what Visser ate and the clothes that she wore. Prinsloo requested that Visser go on a proteinshake diet to the exclusion of other food, as he 'hated cellulite'. When asked why she tolerated this, Visser testified 'I wanted to please Dirk'. Visser testified that sex with Prinsloo was brutal and without love, and that she was subjected to degrading acts with foreign objects such as cucumbers, carrots and a firearm. She was also forced into acts with dogs.

Prinsloo also fantasised about having sex with young girls. Some of the charges against Prinsloo and Visser related to young girls whom they fetched from an orphanage under the guise of wanting to treat the girls for weekend visits at their home. One girl was 15 years old, the other girl was 11 years old. The charges relate to various sexual offences including indecent assault, rape and incitement of a minor into sexual acts. These minors were collected from an orphanage in Pretoria for so-called 'weekend visits'. The evidence revealed that the girls were provided with drinks, often 'Milo' which contained sedative drugs after which various sexual acts were performed on them by Prinsloo.

Visser admitted to performing oral sex on Prinsloo in front of the 15-year-old girl and having sex with Prinsloo in front of the 11-year-old

\footnotetext{
Africans as 'Advocate Barbie' faced 14 charges against her which included fraud, the incitement of minors to commit indecent acts, indecent assault, rape, possession of child pornography, the manufacturing of child pornography as well as the possession of drugs. The case was heard in part in the Pretoria High Court, but was halted in April 2007 when the judge passed away. The case again commenced on 16 February 2009. Cézanne Visser initially stood trial on all of the charges together with her former lover and fiancé, Dirk Prinsloo. Dirk Prinsloo, however, left the country in 2006 and was one of Interpol's most wanted criminals. On 12 June 2009 Dirk Prinsloo was arrested in Belarus for an attempted bank robbery. He also faced charges of theft, hooliganism and torture. On 1 February 2010 he was convicted of theft, bank robbery and hooliganism and sentenced to 13 years in jail. At her trial, Visser's defence was based on the battered woman syndrome and, more specifically, on the coercive control that Prinsloo exerted over her throughout her relationship. Her defence also rested on the fact that her actions showed signs of suffering from Stockholm syndrome and the compliant victim syndrome, which are discussed below.
} 
girl. When asked why she performed these acts, Visser stated: 'I said it before and I say it now, Dirk spoke and I did. I have no idea why, but that is how it was'.

Visser testified that she had committed the acts as a result of the abuse and coercive control Prinsloo exerted over her. She asserted that she was subjected to various forms of degradation, which included drinking Prinsloo's urine and smearing his faeces on herself. The latter was her punishment if she did not behave as Prinsloo wanted her to. Visser also stated in evidence that Prinsloo was addicted to sex and even went as far as forcing her to have sex in a chapel.

In support of Visser's defence that she suffered from battered woman syndrome, Professor Jonathan Scholtz, head of clinical psychology at Weskoppies Hospital, testified that although Prinsloo initially appeared to be Visser's knight in shining armour, charming her and purporting to save her from an abusive family situation, he systematically and deliberately took control of her and shaped her to his needs. Scholtz further stated that Visser's parents' unhappy marriage, the values installed in her during childhood and her low esteem made her the perfect target for Prinsloo.

Scholtz testified that while Visser was highly intelligent, she was naïve and mentally immature. According to Scholtz, Prinsloo took complete control over Visser-her appearance, what she ate, when she slept and with whom she spoke. She was exposed to perverse acts with multiple people. Scholtz testified that in his opinion, Visser was subjected to severe domestic abuse and coercive control.

It is accordingly both relevant and topical to assess the phenomena of coercive control and the Stockholm syndrome, as well as the theory of the compliant victim of the sexual sadist, as advanced in the Visser trial, as the recognition of such psychological manifestations of abuse is relatively new. These psychological dimensions of abuse within intimate relationships could, in addition, become relevant whenever a court is faced with the assessment of battered woman syndrome evidence advanced in support of a particular defence in criminal law. It is to be noted that although these phenomena are addressed against the backdrop of a South African case, it could have international impact in terms of providing new perspectives on abuse within intimate relationships.

\section{Reflections on the psychological manifestations of coercive control, the Stockholm syndrome and the compliant victim of the sexual sadist}

\section{Coercive control}

Coercive control in intimate partnerships is generally typified by a pattern of power and control and such control manifests itself in mainly intimidation, emotional abuse and isolation, minimising assertion of male privilege, coercion and threats. ${ }^{2}$

2 J. B. Kelly and M. P. Johnson, ‘Differentiation among Types of Intimate Partner Violence: Research Update and Implications for Interventions' (2008) 46(3) Family Court Review 476 at 481. See also M. P. Johnson, 'Conflict and Control: Gender Symmetry and Asymmetry in Domestic Violence' (2006) 12 Violence Against Women 1003. 
Such tactics can be employed effectively without the use of violence and, as such, coercive control does not generally manifest in high levels of violence. ${ }^{3}$ Research suggests that within heterosexual relationships coercive control is perpetrated primarily by men. ${ }^{4}$ The psychological effects of coercive control include fear, anxiety, loss of self-esteem, depression and post-traumatic stress syndrome. ${ }^{5}$

Stark describes coercive control as follows: ${ }^{6}$

... the clinical profile revealed by battered women reflects the fact that they have been subjected to an on-going strategy of intimidation, isolation and control that extends to all areas of a woman's life, including sexuality, material necessities, relations with family, children and friends, and work. Sporadic, even severe violence makes this strategy of control effective. But the unique profile of the battered woman arises from the deprivation of liberty implied by coercion and control as it does from violence induced trauma.

Coercive control accordingly establishes an ongoing pattern of sexual mastery in terms of which abusive partners, predominantly males, employ three important tactics: intimidation, isolation and control. ${ }^{7}$ Stark conceptualises the latter by stating: ${ }^{8}$

Coercive control entails a malevolent course of conduct that subordinates women to an alien will by violating their physical integrity (domestic violence), denying them respect and autonomy (intimidation), depriving them of social connectedness (isolation), and appropriating or denying them access to the resources required for personhood and citizenship.

It, accordingly, becomes problematic to view domestic abuse safely through the prism of the incident-specific and injury-based definition of violence, thereby negating the multi-dimensionality of oppression and control in personal life. ${ }^{9}$ Coercive control can also often result in the victim identifying with the abuser which entails that the abused woman will attempt to view the world through the eyes of the abuser in a desperate attempt to prevent further harm and danger. ${ }^{10}$ By means of the systematic and repetitive infliction of psychological trauma coupled with violence, terror and helplessness become part of the abused woman and systematically her sense of self is eliminated. ${ }^{11}$ Control can consist of various forms of deprivation, exploitation and commanding behaviour that compel obedience in an indirect manner by monopolising important resources, dictating choices,

3 Kelly and Johnson, 'Differentiation among Types of Intimate Partner Violence', above n. 2 at 481 .

4 Ibid. at 482.

5 Ibid. at 483. See also in general, V. N. Chang, I Just Lost Myself: Psychological Abuse of Women in Marriage (Praeger: Westport CT, 1996).

6 E. Stark, Coercive Control: How Men Entrap Women in Personal Life (Oxford University Press: Oxford, 2007) 57. See also E. Stark, 'Re-presenting Woman Battering: From Battered Woman Syndrome to Coercive Control' (1995) 3 Albany Law Review 57.

7 Stark, Coercive Control, above n. 6 at 5. Coercive control is often referred to as coerced persuasion; conjugal, patriarchal or intimate terrorism; emotional or psychological abuse; indirect abuse or emotional torture.

8 Ibid. at 15.

9 Ibid. at 14-15.

10 H. Ludsin and L. Vetten, Spiral of Entrapment-Abused Women in Conflict with the Law (Jacana Media: 2005) 67.

11 Ibid. at 68 . 
micro-regulating the woman's behaviour, restricting her options and depriving her of support essential to the execution of independent judgement. ${ }^{12}$ In attempting to view things in the way that the abuser does, the abused woman adopts the abuser's outlook and believes that she is the cause for the abuse and that she deserves it. ${ }^{13}$ This is also referred to as 'identification with the aggressor' and eventually results in the woman's identity being defined by the abusive partner. ${ }^{14}$

In terms of coercive control, sexual coercion is often a prominent feature of the exercise of control. Women are, in addition, frequently forced to have sex against their will often or all the time. ${ }^{15}$ According to Ludsin and Vetten, sexual abuse serves not only as a means of control, but also constitutes a form of degradation. ${ }^{16}$ In situations of coercive control, an abuser may also regulate what the woman eats, when she sleeps and what she should wear. ${ }^{17}$ Coercive control can also comprise of various monitoring and surveillance tactics which may include phoning or arriving at the woman's place of work in order to ensure that she is indeed at work or checking the calls made from her cell phone. ${ }^{18}$

Isolation is another prominent feature of the coercive control model. Controllers generally isolate their partners with the aim of preventing disclosure, to instil dependence and also to restrict the woman's skills and resources in order to prevent her from seeking help and support. ${ }^{19}$ The abusive partner will accordingly isolate the woman from her friends, family and other support systems and limit her contact with others to those who support the controller's or abuser's perspectives. ${ }^{20}$

Eventually the abusive partner becomes omnipotent and omnipresent with complete control over the abused woman.

\section{The Stockholm syndrome}

The Stockholm syndrome is a psychological response often observed in abducted hostages, in which the hostage displays signs of loyalty to the hostage taker, regardless of the danger or risk they find themselves in. The syndrome is named after the Norrmalmstorg robbery of the kreditbanken at Norrmalmstorg, Stockholm, Sweden in which the bank robbers held bank employees hostage from August 23 to August 28 1973. The victims became emotionally attached to their victimisers and eventually even defended their captors after they were freed from their six-day ordeal. ${ }^{21}$

12 Stark, Coercive Control, above n. 6 at 228.

13 Ludsin and Vetten, above n. 10 at 69.

14 Ibid.

15 Stark, Coercive Control, above n. 6 at 250-71.

16 Ludsin and Vetten, above n. 10 at 71.

17 Ibid. at 72 .

18 Stark Coercive Control, above n. 6 at 255; Ludsin and Vetten, above n. 10 at 72.

19 Stark, Coercive Control, above n. 6 at 262.

20 Ludsin and Vetten, above n. 10 at 72.

21 Ibid. at 73-4. See J. M. Carver, 'Love and Stockholm Syndrome: The Mystery of Loving an Abuser', Counselling Resource, Mental Health Library, available at http:// counsellingresource.com/lib/therapy/self-help/stockholm/, accessed 22 February 2014. See also T. A. Orava, P. J. Mcleod and D. Sharpe, 'Perceptions of Control, Depressive Symptomatology, and Self-esteem of Women in Transition from Abusive Relationships' (1996) 11 (2) Journal of Family Violence 167. 
In terms of the Stockholm syndrome captives begin to identify with their captors initially as a defensive mechanism, out of fear of further violence. Stockholm syndrome is also commonly encountered in abusive relationships and is accordingly used as a model of explaining why an abused woman did not leave her abusive husband.

Every syndrome has symptoms or behaviours, and Stockholm syndrome is no exception. While a clear-cut list has not been established due to varying opinions by researchers and experts, several of the following features will be present:22

1. Positive feelings by the victim toward the abuser/controller.

2. Negative feelings of victims towards family, friends, or authorities trying to rescue/support them or win their release.

3. Support of the abuser's reasons and behaviours.

4. Positive feelings by the abuser towards the victim.

5. Supportive behaviours by the victim, at times helping the abuser.

6. Inability to engage in behaviours that may assist in the victim's release or detachment.

The Stockholm syndrome produces an unhealthy bond with the controller and abuser. It is the reason why many victims continue to support an abuser even after a relationship has ended. It could also be used to explain why abused women continue to see 'the good side' of an abuser and appear sympathetic to someone who has mentally and, most often, psychologically abused them.

\section{The compliant victim of the sexual sadist}

Abused women involved in sexual and violent crimes have been referred to as compliant victims 'in order to illustrate their submissive cooperation in their own and others' victimisation'.$^{23}$ These relationships are typified by the most brutal forms of sexual violence and comprise the complete transformation of the woman's sense of self and also her behaviour in response to intimate contact and the sexual fantasies and desires of the sadistic male. ${ }^{24}$ Hazelwood, Warren and Dietz state that a battered woman of a sexual sadist experiences a process of coercion similar to brainwashing. ${ }^{25}$ Accordingly, these women are subject to a process of manipulation of various rewards and punishments within a context of social isolation which 'can alter self-concept, expectations, and behaviours among at least some victims'. ${ }^{26}$ To the average lay observer these women seem to be consensually submitting to abuse despite the opportunities they have to escape from the abuse. ${ }^{27}$

22 Ludsin and Vetten, above n. 10 at 73-4.

23 F. E. Chapman, 'The Compliant Victim of the Sexual Sadist and the Proposed Canadian Defence of Coercive Persuasion', paper submitted at the International Society for the Reform of Criminal Law, 22nd International Conference Codifying the Criminal Law: Modern Initiatives (2008) Dublin; J. I. Warren and R. R. Hazelwood, Relational Patterns Associated with Sexual Sadism: A Study of 20 Wives and Girlfriends' (2002) 17 Journal of Family Violence 75 at 77.

24 Warren and Dietz, above n. 23 at 77.

25 R. Hazelwood, J. Warren and P. Dietz, 'Compliant Victims of the Sexual Sadist' (1993) 22 Australian Family Physician 474.

26 Ibid.

27 Ibid. 
In terms of this form of domestic violence the 'captor' seeks compliance as well as opportunities for continued abuse. ${ }^{28}$ The motivation for the woman to submit herself to the acts of the abuser is not simply to please him and, in some instances, the women become assimilated into the sexual aggression of their partners. ${ }^{29}$ The woman's response to the paraphilic interest of the man may also be conceived by the gradual assimilation of behaviour that integrates the sadist's sexual fantasies into her own behaviour. ${ }^{30}$

What is striking is that most women within this type of abusive relationship are successful professionally when they meet the abuser. ${ }^{31}$ Sexual sadists often prefer professional women as they have the desire to prove that they can transform an independent, competent woman, who comes from a nice middle-class family, reducing her to a 'sexual slave' willing to join them in any act no matter how degrading or humiliating. ${ }^{32}$ These relationships are also categorised with physical, emotional and psychological and sexual abuse. ${ }^{33}$

A further intrinsic and prominent feature of abuse within this context relates to the process of transformation women undergo from relatively normal patterns of living to completely bizarre, destructive and dangerous forms of exploitation and perversion. ${ }^{34}$

Hazelwood, Warren and Dietz state: ${ }^{35}$

Having met, seduced and transformed a 'nice' woman into a sexually compliant and totally dependent individual, the sadist has validated his theory of women. The woman is now a subservient inferior being who has allowed herself to be recreated sexually and has participated in sexual acts that no decent woman would engage in, thereby confirming that she is a 'bitch' and deserving of punishment.

Expert evidence in cases of this nature will be crucial to explain why the woman engaged in criminal activities with the abusive partner who may also very well be a sexual sadist. The coercive control model for explaining attachment and bonding within an abusive relationship has always been present, yet it is relatively new in terms of the recognition of this theory in explaining the behaviour of abused women.

When applying the abovementioned principles pertaining to the abused woman as a compliant victim of sexual sadistic abuse, there are striking resemblances to the evidence tendered in the trial of Cézanne Visser. Prinsloo displayed clear signs of sexual sadism, whilst Visser displayed signs of the typical compliant victim. Visser also testified that kinky sexual acts were as normal as 'brushing teeth' and that she was a victim in a relationship which was not normal.

28 Above n. 25.

29 Chapman, above n. 23 at 16.

30 Hazelwood, Warren and Dietz, above n. 25 at 474.

31 Ibid. at 99.

32 Chapman, above n. 23 at 20-1.

33 Ibid.

34 Hazelwood, Warren and Dietz, above n. 25 at 99.

35 Ibid. at 99-100. 


\section{Barbie's fate}

Visser was convicted on 11 of the 14 charges, which included indecent assault of children and adults, fraud and possession and manufacture of child pornography, on 6 and 7 October 2009. In delivering judgment, Eksteen AJ ultimately rejected her defence of having been under the 'spell' or coercive control of her lover, Prinsloo. It was, in addition, held that Prinsloo was often not present when Visser exposed herself to the children. Eksteen AJ found that Visser did not follow everything Prinsloo instructed her to do and held that Visser sought to hide behind Prinsloo's conduct to justify her own actions, referring specifically to her claim that Prinsloo was manipulative and as a result she had no will of her own. Eksteen AJ held that it was improbable that Visser was caught in Prinsloo's web as she had freedom of movement and there was also evidence to the effect that she could stand up to Prinsloo. The court also concluded that:

1. Visser was a willing partner in the sexual abuse of the three children and the three young women;

2. Visser willingly participated in the various sexual acts perpetrated on the victims at the Prinsloo home and she embraced the new life Prinsloo offered her;

3. Visser took the initiative in locating some of the victims;

4. Visser's conduct was aimed at obtaining children and women to abuse them sexually for her and Prinsloo's own gain;

5. Visser and Prinsloo had sex in front of some of the children to solicit them to commit indecent acts;

6. Visser was aware of the fact that medication was utilised by Prinsloo to drug some of the victims and that their drinks were spiked;

7. many of the acts against the children were committed in Prinsloo's absence;

8. Visser went to an orphanage and informed management that she and Prinsloo were married in order to persuade them to allow the children to visit them for weekends;

9. Visser took the children home knowing perfectly well what fate awaited them there.

On 24 February 2010 Visser was sentenced to an effective term of seven years' imprisonment. Leave to appeal to the Supreme Court of Appeal in Bloemfontein against her conviction was rejected on 13 May 2010 by Judges Mohamed Navsa and Belinda Van Heerden. Visser resumed serving her sentence and was paroled under strict conditions in August 2013.

\section{Conclusion}

In this article the battered woman syndrome has been revisited with specific emphasis on the non-visible aspects of abuse within intimate relationships. The specific manifestations of coercive control, the Stockholm syndrome and the compliant victim of the sexual sadist have been reflected upon against the backdrop of the highly publicised trial of 
Cézanne Visser in South Africa. Although these phenomena, or manifestations of them, have probably been present in abusive relationships for many decades, the recognition of them within abusive relationships is fairly recent.

The conviction of Visser and her application for leave to appeal against her conviction not only gave rise to immense publicity in South Africa, but also highlighted the age-old phenomena of abuse within an intimate relationship. Aspects of the effects of coercive control in a relationship, the Stockholm syndrome and the compliant victim of the sexual sadist were brought to the fore and even though their importance to the court's decision in the Visser case remains dubious, the emphasis placed on such matters during and after the trial can be seen as a positive step towards taking cognisance not only of the visible or physical aspects of abuse within intimate relationships, but also the invisible and often-concealed forms of abuse conducted behind closed doors. Domestic abuse encompasses numerous manifestations, of which physical abuse is but one example. It is therefore crucial to acknowledge other types of abuse considered here such as coercive control, the Stockholm syndrome and the compliant victim as these are frequently encountered within abusive relationships and their impact and intensity are often underestimated. Every abusive relationship will have its own distinctive semantics distinguishing it from other abusive relationships. The fact that the defence as put forward in the Visser trial was rejected should not be construed as closing the door on the defence in cases where abused partners subjected to coercive control and manipulation commit crimes. What becomes abundantly clear is that courts will approach such defences with circumspection, thus necessitating the need for effective expert testimony in support of them. In Visser's case, it could at least be argued that the defence contributed to mitigation of sentence. The distinguishing factor of the decision as opposed to other cases dealing with abuse is the fact that Visser's actions were not directed against her abuser, but primarily against innocent third parties or victims. Usually within an abusive relationship the abused partner retreats and directs his or her actions against the abuser. The conduct of Prinsloo towards Visser was, however, at certain stages so vile that it seems probable that she was controlled by him-whether such control was of such a nature and degree in order to render Visser powerless to withstand Prinsloo's demands remains questionable. The undeniable fact is, however, that no matter how much empathy a court retains for a victim of abuse such as Visser, the court also has a duty to uphold justice for the innocent victims and also to safeguard the interests of minor children and their right to be protected from all forms of sexual abuse. It is submitted that this duty can be construed as one of the overriding factors negating Visser's defence.

In conclusion, the following quote serves to express the theme of this article:

Coercive control theory explains many features of abusive relationships that puzzle people-such as the woman's loyalty and attachment to her partner in the face of her great fear of him. It illustrates how these features exist not only in situations of domestic violence but also in other situations where people are held captive. Like others who have been prisoners of war, political prisoners, 
hostages, or cult survivors, battered women have been subjected to on-going processes of intimidation and abuse that systematically degrade their sense of self over time and isolate them from others. ${ }^{36}$

36 Ludsin and Vetten, above n. 10 at 75. 